\title{
Energy Planning and Sustainable Biogas Production Prospect Within Residential Quarters in Developing Countries
}

\author{
Emetere Moses E., Adesina Tijesuni
}

\begin{abstract}
The prospects of biogas as a major energy option to alleviate the energy needs in Africa is huge based on its teeming population. However, the main source of biogas i.e. human excretal is being neglected, thereby loosing resource worth 500 MW of electricity. This research is geared towards estimating the accruable biogas that can be harnessed in a typical student hostel in a developing country. The data was collected at the main chamber of the hostel. The estimation of the optimized state of methane, hydrogen sulphide and carbon dioxide is given as 12\%, $0.94 \%$ and $4.42 \%$ respectively. It was also affirmed that the algae growth on the walls of the sewage line is responsible for the low carbon dioxide values. Also, it was reported that the production of hydrogen sulphide gas is predictable, as it is not directly related to the concentration of microorganism in the sewage chamber. This research gives an eye-opener on biogas wastage in developing countries.
\end{abstract}

Keywords: biogas, renewable energy, energy planning, energy.

\section{INTRODUCTION}

$\mathrm{E}$ nergy demand in Nigeria has been increasing on a relatively high rate; the need for alternative energy sources cannot be over emphasized [1,2]. Currently there is a huge waste of resources around us e.g. biogas [3-4]. Hence, there is the need to enlighten policy maker, government, public and rural dweller on the need to harness biogas resources around us. Biogas is a combination of gases that is given without the presence of oxygen by the biological disintegration of organic matter. It uses organic waste such as animal waste, dead plants, kitchen remains and human waste and can be transformed into biogas fuel [5-9]. Biogas is a gaseous fuel gotten from biomass by the process of anaerobic digestion when bacteria decay biological material in the absence of oxygen. The raw material to the biogas plant for the production of biogas includes manure, green waste, sewage, agricultural waste, garbage etc [3-9]. Aside the economic

Revised Manuscript Received on December 30, 2019.

* Correspondence Author

Emetere Moses E *, Department of Physics, Covenant University Canaan land, P.M.B 1023, Ota, Nigeria. Department of Mechanical Engineering Science, University of Johannesburg, South Africa. emetere@yahoo.com

Adeyemo Nehemiah, Department of Physics, Covenant University Canaan land, P.M.B 1023, Ota, Nigeria.

(C) The Authors. Published by Blue Eyes Intelligence Engineering and Sciences Publication (BEIESP). This is an open access article under the CC BY-NC-ND license (http://creativecommons.org/licenses/by-nc-nd/4.0/) importance of biogas, it curbs deforestation via the use of firewood for cooking and domestic purposes in rural settlement. Also, the adoption of biogas would reduce the use of fossil fuel to control environmental degradation [4,7].

The components of biogas methane (CH4), carbon dioxide (CO2) and sometimes contain small amounts of hydrogen sulphide (H2S). Carbon monoxide and Methane are combustible with oxygen [9]. This release of energy enables the use of biogas as a gas engine fuel, cooking etc. Just like natural gas, the biogas can also be compressed into bio-CNG (compressed natural gas) and used to power motor vehicles $[7,9]$, for example in the UK, biogas is estimated to have the potential of replacing around $17 \%$ of vehicle fuel [10]. Biogas can be upgraded to natural gas standards i.e. bio methane. Biogas is classified based on its source or raw materials. For example, there is the agricultural landfill biogas, wood waste biogas and industrial and urban biogas wastes. The landfill gas is produced in sanitary landfills by the decay of organic matter under the influence of micro organisms that thrive via anaerobic digestion [11-13]. Biogas from wastewater is produced in water treatment plant [14]. Agricultural biogas is produced from waste - leftover agricultural products e.g. livestock, plant residues and any other type of waste material associated with materials that have high carbon content [15].

The aim of this research is to estimate the accruable biogas that can be tapped from student hostel in developing countries. This research focuses on a statistical analysis and optimization of biogas resources. This research is very essential for researcher in developing countries to start thinking on how to assess the huge biogas waste from potential sources.

\section{MATERIALS AND METHOD}

The student hostel used for this research is located in a university in Ota, Nigeria. The methodology applied for this research is described in the flow chart presented in Figure 1. There are about four hundred rooms with toilet facilities (Figure 2). Almost five hundred students make use of the toilet facility. The data collection point was the connecting chamber (within the building vicinity) linking the central sewage system (see red arrow in Figure 2a). This chamber is particularly important because other chambers are connected to it (broken red line in Figure 2b). However, the chamber is not totally sealed when the measurement was taken. 


\section{Energy Planning and Sustainable Biogas Production Prospect Within Residential Quarters in Developing Countries}

Three rounds of measurement were taken in the research sight. The parameter that was considered was methane, hydrogen sulfide and carbon dioxide.

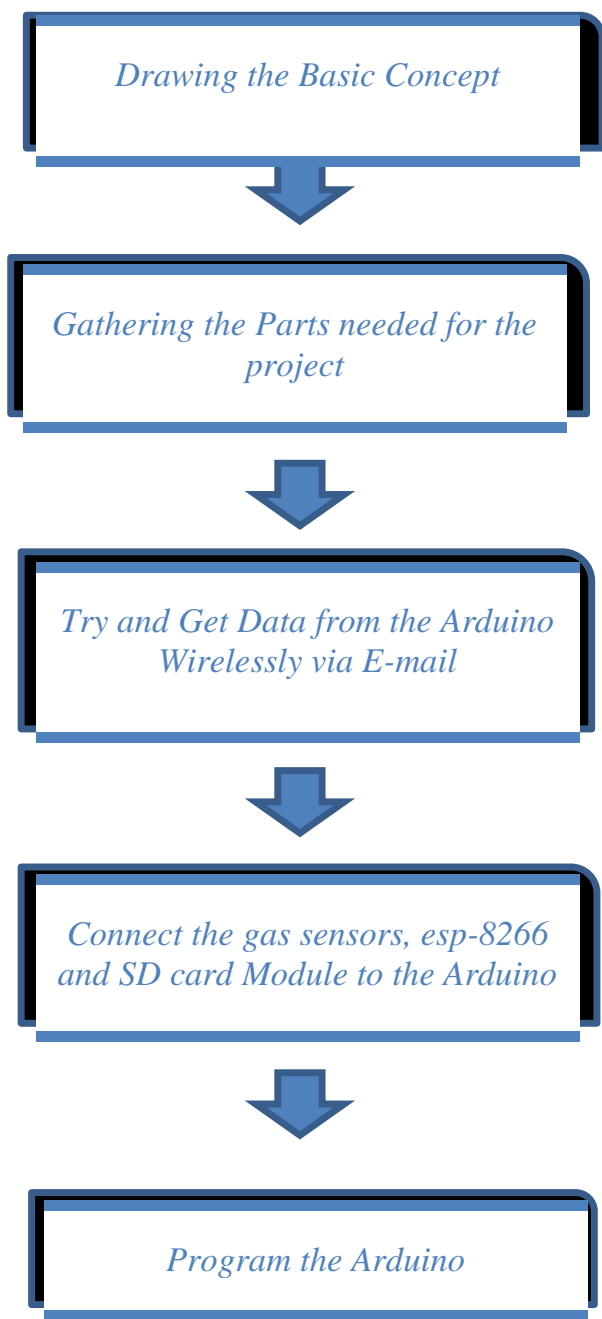

Figure1 - Flow chart of biogas data logger and analysis

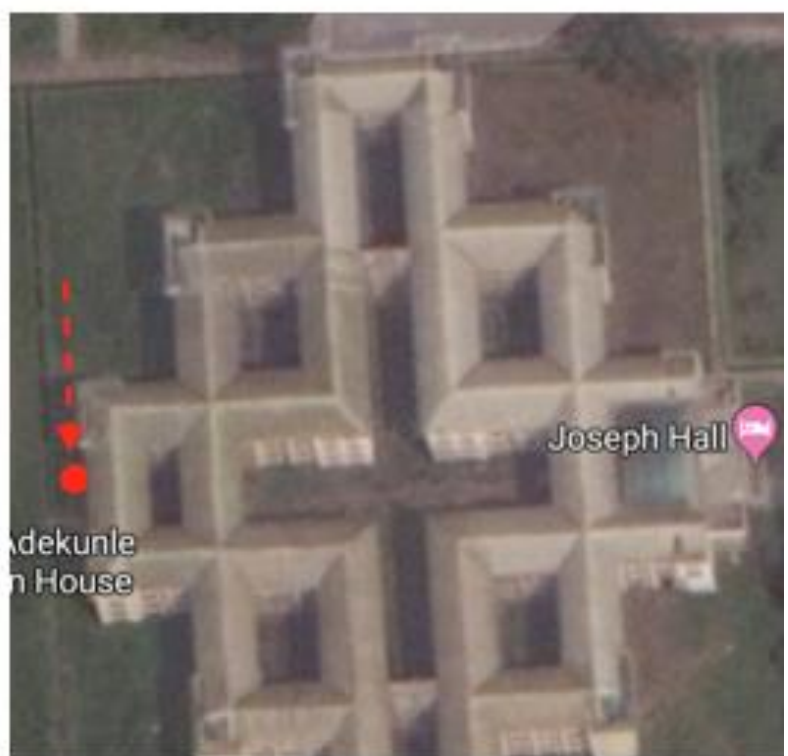

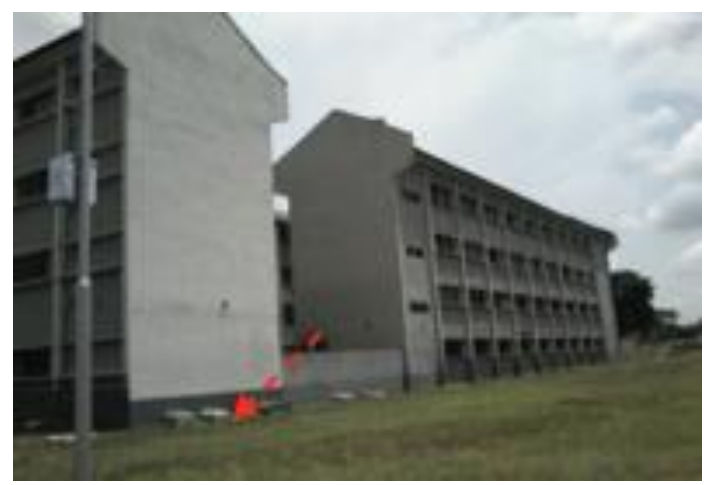

Figure 2: Student residential building

\section{RESULTS AND DISCUSSION}

The legend in the diagrams presented below are $\mathrm{B}$ (i.e. trial 1), C (i.e. trial 2), and D (i.e. trial 3). The methane production is found to be between 140-238 (ppm). It was observed the methane production reduced towards the evening. There are three scenarios that may be responsible for this result. First, it is believe that more users are likely to be around in the evening. Second, the anaerobic state was altered due to a drop in ambient temperature in the sewage line. Third, there was less volume of faeces as it has been transported to the central sewage facility. The average volume of methane gas that was produced within the measurement is $192 \mathrm{ppm}$. The principal component analysis (PCA) was performed to be able to estimate the biogas resources (Figure 4).

The principal component analysis is a statistical procedure that uses an orthogonal transformation to convert a set of observations of possibly correlated variables into a set of values of linearly uncorrelated variables called principal components. In this analysis, three components are used i.e. component 1, component 2 and component 3 . In the PCA graph, the horizontal component refers to the line that passes through the origin and maximizes the variance of the datasets. The vertical component is the uncorrelated factor in the horizontal component that makes it possible to determine the next highest variance. The scattered plot of the principal components of trial 1, $2 \& 3$ are presented in Figure 4. Figure 4a presents the PCA scattered plot for trial 1 and 2; Figure $4 \mathrm{~b}$ presents the PCA scattered plot for trial 1 and 3; Figure 4c presents the PCA scattered plot for trial 2 and 3.

The scattered plot (of trial 1) in Figure 4a shows that the relationship is tilted towards the negative components of trial $1 \& 2$. This depicts that the predictability of the methane production cannot be ascertained because it depends on various factors such as anaerobic condition, microorganism concentration, duration of faeces in the chamber etc. Figure $4 \mathrm{~b}$ shows that trial 2 is not predictable as trial 1 . Figure 4c shows an almost uniform scattered plot in all direction. Though the value was lower, it can be predicted. The principal component (PC) table that shows the eigenvalue and variance in each trial is presented in Table 1.

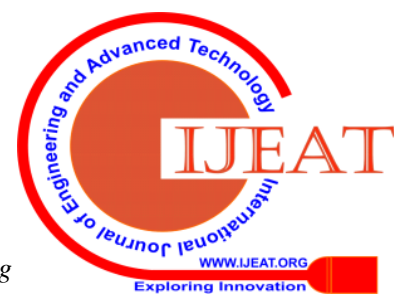




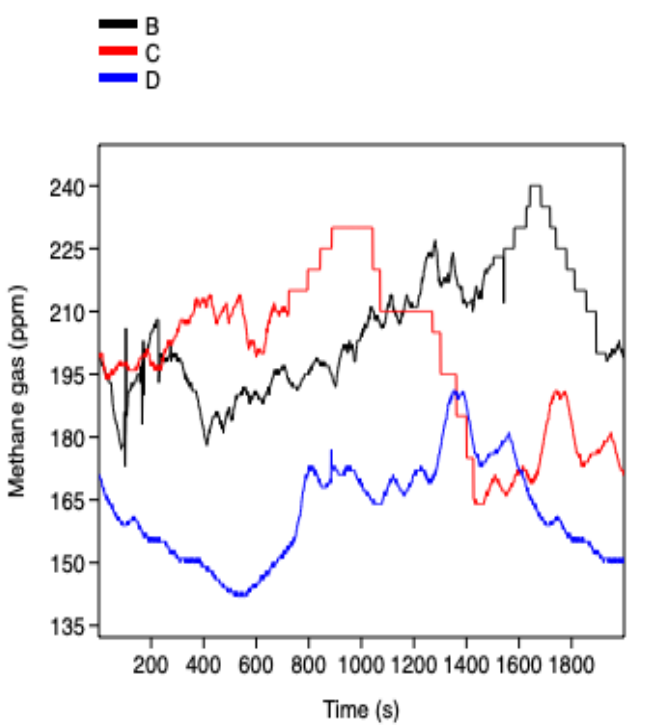

Figure 3: Methane production in research site
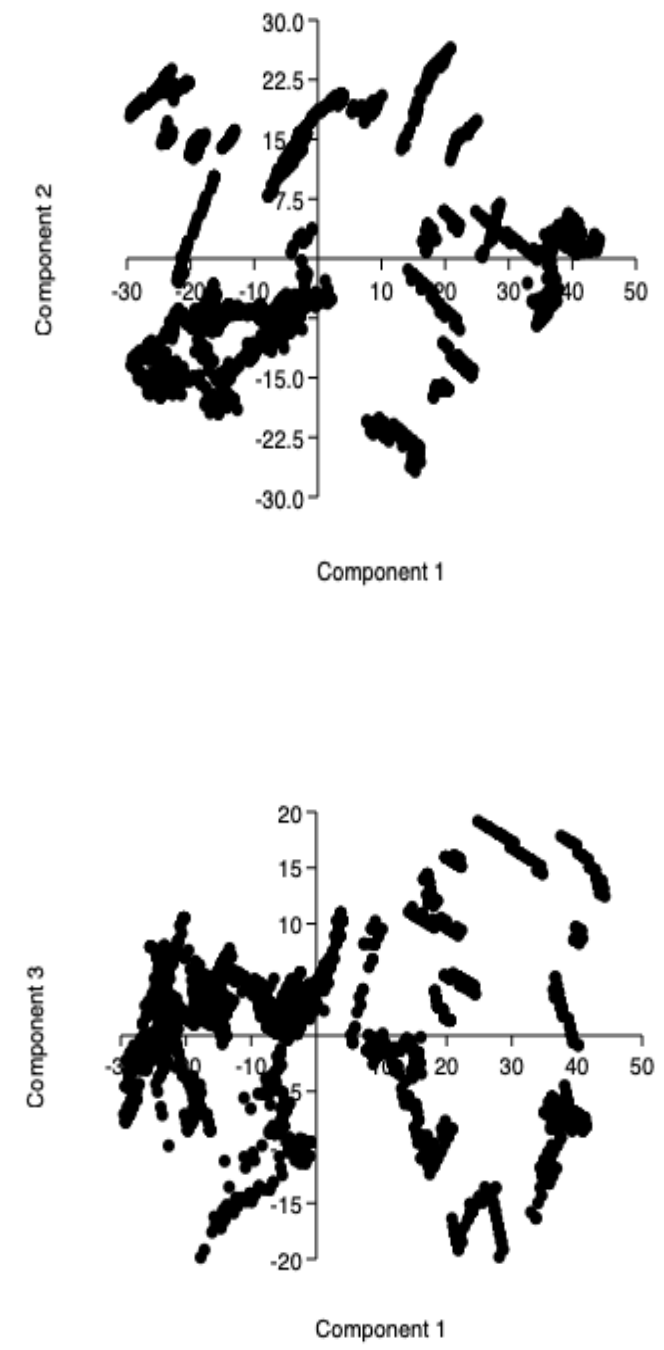

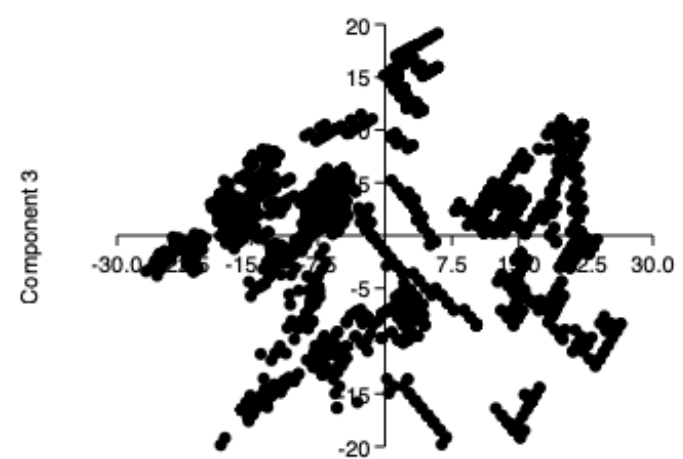

Component 2

Figure 4: Principal component analysis of methane gas

Trial 1 had the highest eigenvalue and variance. The eigenvalue clear shows that this process can be optimized to yield about $12 \%$ methane gas. The ANOVA table for all trials i.e. $1,2 \& 3$ is presented in Table 2 . It shows that the dataset has $\mathrm{F}<1$ reliability to be used for optimization process. The intraclass correlation of each trial is presented in table 3 . It was observed that the second measurement (trial 2) was more reliable i.e. compared to other measurements.

Table 1: Principal component assessments of methane gas trials

\begin{tabular}{|l|l|l|}
\hline PC & Eigenvalue & \% Variance \\
\hline 1 & 461.991 & 65.939 \\
\hline 2 & 180.635 & 25.782 \\
\hline 3 & 58.0103 & 8.2797 \\
\hline
\end{tabular}

Table 2: ANOVA table for methane gas

\begin{tabular}{|l|l|l|l|l|}
\hline & Sum of sqrs & df & Mean square & $\mathrm{F}$ \\
\hline $\begin{array}{l}\text { Between } \\
\text { raters: }\end{array}$ & $2.1574 \mathrm{E} 06$ & 2 & $1.0787 \mathrm{E} 06$ & 4129 \\
\hline $\begin{array}{l}\text { Between } \\
\text { cases: }\end{array}$ & 356057 & 1999 & 178.118 & 0.6818 \\
\hline $\begin{array}{l}\text { Within } \\
\text { cases: }\end{array}$ & $3.20192 \mathrm{E} 06$ & 4000 & 800.48 & \\
\hline Residual: & $1.04452 \mathrm{E} 06$ & 3998 & 261.26 & \\
\hline Total: & $3.55797 \mathrm{E} 06$ & 5999 & & \\
\hline
\end{tabular}


Energy Planning and Sustainable Biogas Production Prospect Within Residential Quarters in Developing Countries

Table 3: Intraclass correlation of each methane gas trials

\begin{tabular}{|l|l|l|l|l|}
\hline & & ICC & & $95 \%$ confidence \\
\hline $\begin{array}{l}\text { Trial } \\
1\end{array}$ & Individual & $(1,1)$ & -0.3498 & {$[-0.3597,-0.3392]$} \\
\hline $\begin{array}{l}\text { Trial } \\
2\end{array}$ & Mean & $(1, \mathrm{k})$ & -3.494 & {$[-3.846,-3.163]$} \\
\hline $\begin{array}{l}\text { Trial } \\
3\end{array}$ & Individual & $(2,1)$ & -0.03586 & {$[-0.07906,0.01804]$} \\
\hline & Mean & $(2, \mathrm{k})$ & -0.1159 & {$[-0.2817,0.05225]$} \\
\hline
\end{tabular}

The hydrogen sulphide production (Figure 5) is found to be between 82.5-142.5 (ppm). It was observed the hydrogen sulphide production also decreased towards the evening. The likely reasons have been previously discussed. The average volume of hydrogen sulphide gas that was produced within the measurement is $\approx 98 \mathrm{ppm}$. The principal component analysis (PCA) is presented in Figure 6. Figure 6a-c shows the linearity of the trial 1 in relation to other trials. It can infer that the production of hydrogen sulphide gas is predictable, as it is not directly related to the concentration of microorganism in the sewage chamber.

$$
\text { 三 }_{\mathrm{D}}^{\mathrm{B}}
$$

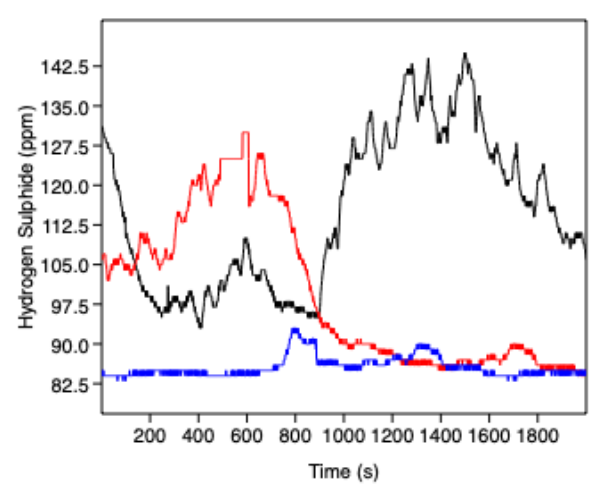

Figure 5: Hydrogen sulphide production in research site

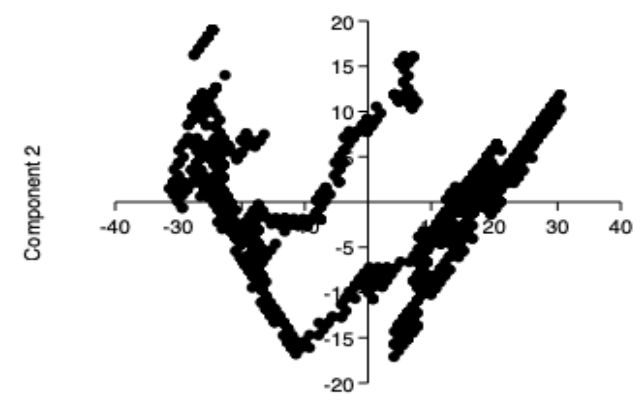

Component 1

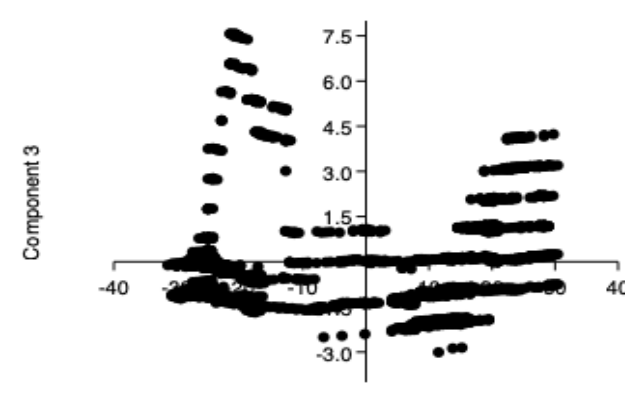

Component 1

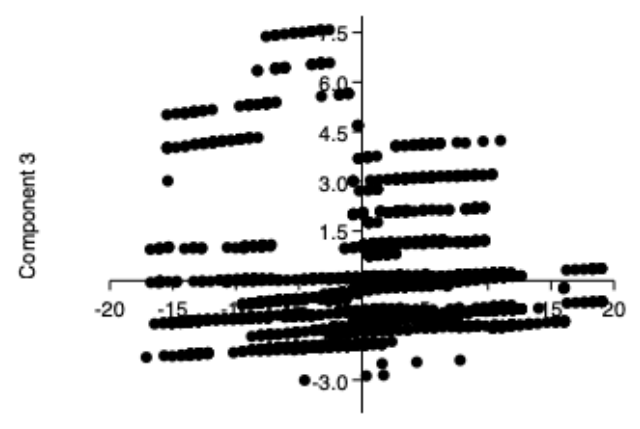

Component 2

Figure 6: Principal component analysis of hydrogen sulphide gas

The eigenvalue reveal (Table 4) that the production of hydrogen sulphide can be optimized by $0.94 \%$. The ANOVA table (Table 5) shows that the dataset has $\mathrm{F}<1$ reliability to be used for optimization process. Like in Table 3, it was observed that the second measurement (trial 2) was more reliable i.e. compared to other measurements (Table 6).

Table 4: Principal component assessments of hydrogen sulfide gas trials

\begin{tabular}{|l|l|l|}
\hline PC & Eigenvalue & \% variance \\
\hline 1 & 363.135 & 85.816 \\
\hline 2 & 56.4548 & 13.341 \\
\hline 3 & 3.5645 & 0.84236 \\
\hline
\end{tabular}

Table 5: ANOVA table for hydrogen sulphide gas

\begin{tabular}{|l|l|l|l|l|}
\hline & Sum of sqrs & df & $\begin{array}{l}\text { Mean } \\
\text { square }\end{array}$ & F \\
\hline $\begin{array}{l}\text { Between } \\
\text { raters: }\end{array}$ & 850062 & 2 & 425031 & 2204 \\
\hline
\end{tabular}




\begin{tabular}{|l|l|l|l|l|}
\hline $\begin{array}{l}\text { Between } \\
\text { cases: }\end{array}$ & 74861.4 & 1999 & 37.4494 & 0.1942 \\
\hline $\begin{array}{l}\text { Within } \\
\text { cases: }\end{array}$ & $1.62109 \mathrm{E} 06$ & 4000 & 405.272 & \\
\hline Residual: & 771024 & 3998 & 192.853 & \\
\hline Total: & $1.69595 \mathrm{E} 06$ & 5999 & & \\
\hline
\end{tabular}

Table 6: Intraclass correlation of each hydrogen sulfide gas trials

\begin{tabular}{|l|l|l|l|l|}
\hline & & ICC & & $\begin{array}{l}95 \% \\
\text { confidence }\end{array}$ \\
\hline Trial 1 & Individual & $(1,1)$ & -0.4338 & $\begin{array}{l}{[-0.4384,} \\
-0.4287]\end{array}$ \\
& & & & {$[-10.67$,} \\
& Mean & $(1, \mathrm{k})$ & -9.822 & $-9.026]$ \\
\hline Trial 2 & Individual & $(2,1)$ & -0.1465 & {$[1,-0.1885]$} \\
\hline & Mean & $(2, \mathrm{k})$ & -0.6219 & {$[1,-0.9079]$} \\
\hline Trial 3 & Individual & $(3,1)$ & -0.3672 & {$[-0.3761$,} \\
& & & & $-0.3577]$ \\
\hline & Mean & $(3, \mathrm{k})$ & -4.15 & {$[-4.553$,} \\
& & & & $-3.771]$ \\
\hline
\end{tabular}

The carbon dioxide gas production in the sewage chamber was found to be between 38-47 (ppm). It was observed the carbon dioxide gas production increased towards the evening (Figure 7). Certainly, this result is contrary to the methane and hydrogen sulphide gas. The low carbon dioxide (compared to other gases) may indicate biological conversion taking place along the sewage line. The average volume of carbon dioxide gas that was produced within the measurement is $41 \mathrm{ppm}$.

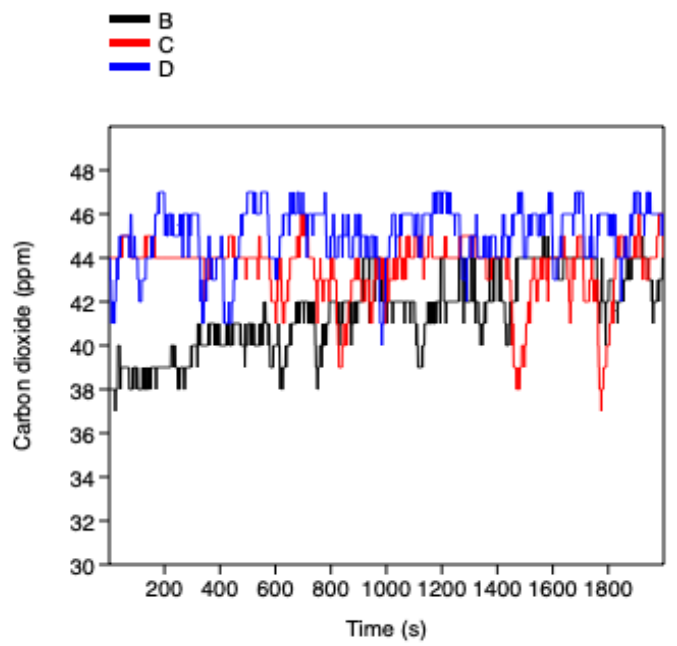

Figure 7: Carbon dioxide production in research site

The principal component analysis (PCA) is presented in Figure 8. Figure 8a-c shows the positive and negative linearity of the group of measured dataset. This further affirms that some biological processes control the carbon dioxide production in the sewage. The work of Bryns et al. [16] affirmed that the algae growth on the walls of the sewage line is responsible for the low carbon dioxide production.
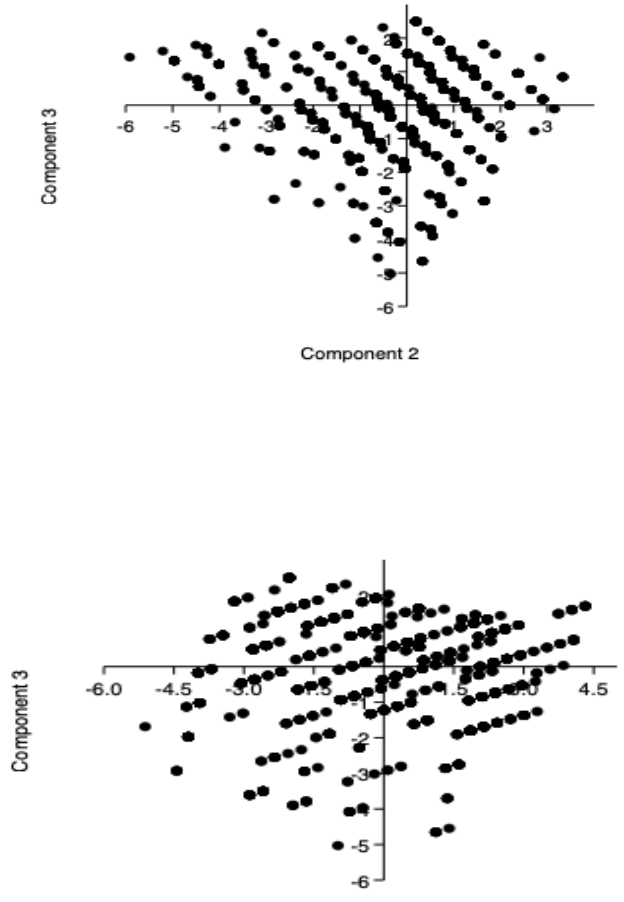

Component 1

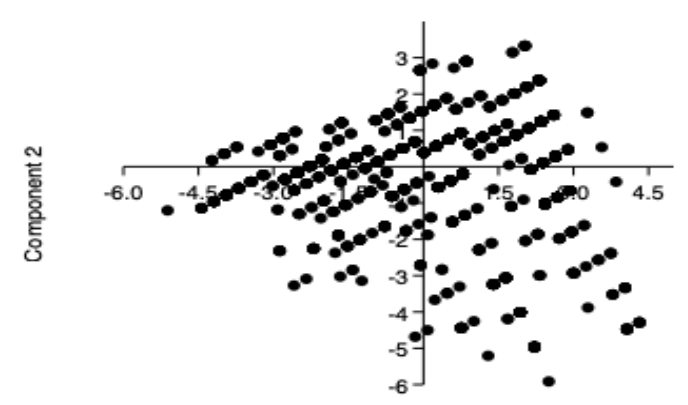

Component 1

Figure 8: Principal component analysis of carbon dioxide gas

The eigenvalue reveal (Table 7) that the production of carbon dioxide can be optimized by $4.42 \%$. The ANOVA table (Table 8) shows that the dataset has $\mathrm{F}<1$ reliability to be used for optimization process. Like in Table $3 \& 6$, it was observed that the second measurement (trial 2) was more reliable i.e. compared to other measurements (Table 9).

Table 7: Principal component assessments of carbon dioxide gas trials

\begin{tabular}{|l|l|l|}
\hline PC & Eigenvalue & \% variance \\
\hline 1 & 3.68508 & 50.59 \\
\hline 2 & 1.91356 & 26.27 \\
\hline 3 & 1.68551 & 23.139 \\
\hline
\end{tabular}




\section{Energy Planning and Sustainable Biogas Production Prospect Within Residential Quarters in Developing}

Countries

Table 8: ANOVA table for carbon dioxide gas

\begin{tabular}{|l|l|l|l|l|}
\hline & Sum of sqrs & df & $\begin{array}{l}\text { Mean } \\
\text { square }\end{array}$ & F \\
\hline $\begin{array}{l}\text { Between } \\
\text { raters: }\end{array}$ & 12604.6 & 2 & 6302.29 & 2557 \\
\hline $\begin{array}{l}\text { Between } \\
\text { cases: }\end{array}$ & 4706.93 & 1999 & 2.35464 & 0.9553 \\
\hline $\begin{array}{l}\text { Within } \\
\text { cases: }\end{array}$ & 22458.7 & 4000 & 5.61467 & \\
\hline Residual: & 9854.08 & 3998 & 2.46475 & \\
\hline Total: & 27165.6 & 5999 & & \\
\hline
\end{tabular}

Table 9: Intraclass correlation of each carbon dioxide gas trials

\begin{tabular}{|l|l|l|l|l|}
\hline & & ICC & & $\begin{array}{l}95 \% \\
\text { confidence }\end{array}$ \\
\hline Trial 1 & Individual & $(1,1)$ & -0.24 & $\begin{array}{l}{[-0.2558,} \\
-0.2232]\end{array}$ \\
& & & & {$[-1.571$,} \\
& Mean & $(1, \mathrm{k})$ & -1.385 & $-1.209]$ \\
\hline Trial 2 & Individual & $(2,1)$ & -0.00658 & {$[-0.01925$,} \\
& & & & $0.006899]$ \\
\hline & Mean & $(2, \mathrm{k})$ & -0.02 & {$[-0.06007$,} \\
& & & & $0.02042]$ \\
\hline Trial 3 & Individual & $(3,1)$ & -0.01512 & {$[-0.03954$,} \\
& & & & $0.0103]$ \\
\hline & Mean & $(3, \mathrm{k})$ & -0.04676 & {$[-0.1288$,} \\
& & & & $0.03026]$ \\
\hline
\end{tabular}

\section{CONCLUSION}

The ANOVA tables shows that the reliance on the dataset for optimization procedure was truer for hydrogen sulphide than methane and carbon dioxide. The estimation of the optimized state of methane, hydrogen sulphide and carbon dioxide is given as $12 \%, 0.94 \%$ and $4.42 \%$ respectively. It was also affirmed that the algae growth on the walls of the sewage line is responsible for the low carbon dioxide production. Also, it was reported that the production of hydrogen sulphide gas is predictable, as it is not directly related to the concentration of microorganism in the sewage chamber. From the above results, the prospects of alleviating energy demands via the adoption of biogas are viable. It is recommended that biogas plants be built close to central sewage system within each community in the rural and urban areas. The success of this recommendation would reduce the use of fossil fuels.

\section{ACKNOWLEDGMENT}

The authors wish to appreciate Covenant University for partial sponsorship.

\section{REFERENCES}

1. Emetere M.E., Okoro U., Etete B., and Okunbor G., (2016), Free energy option and its relevance to improve domestic energy demands in southern Nigeria, Energy Reports, 2, 229-236.
2. Chand (2017) Energy problems in developing countries http://www.yourarticlelibrary.com/essay/energy-problems-in-developi ng-COuntries/39434 (Accessed $28^{\text {th }}$ March 2019)

3. Kemausour, F.; Adaramola, M.S.; Morken, J. (2018), A review of commercial biogas systems and lessons for Africa. Energies , 11: 2984 i'T

4. C. Mulinda, Q. Hu, K. Pan, (2013), Dissemination and problems of African biogas technology, Energy Power Eng., 5(8): 506-512

5. Adelekan, B.A (2002). “Assessing Nigeria's Agricultural Biomass Potential as a Supplementary Energy Resource through Adoption of Biogas Technology". Nigeria Journal of Renewable Energy. Sokoto Energy Research Center 10(1-2): 145-150.

6. Bond, T. (2011). History and future of domestic biogas plants in the developing world. Energy for sustainable development. 15: 347-354. Doi:10.1016/j.esd.2011.09.003.

7. Cuéllar, A. and Webber, M. (2009). "Policy Incentives, Barriers and Recommendations for Biogas Production”. ES2009-90272. 49(2): 50-56.

8. Prasad, S., Rathore, D. and Singh, A. (2017), Recent Advances in Biogas Production. Chemical Engineering \& Process Techniques. 3: 1038-1125.

9. Home Biogas, (2019) Advantages and Disadvantage of Biogas, https://www.homebiogas.com/Blog/141/Advantages_and_Disadvanta ges_of_Biogas (Accessed 28th March 2019)

10. Biotech (2019), Biogas Production, http://www.discoverbiotech.com/industrial-biotechnology-cntrb;jsessi onid=EE934F8220E3392CCE2C96581355D320?p_p_auth=H4mJg3j d\&p_p_id=56_INSTANCE_J6tn\&p_p_lifecycle=0\&p_p_col_id=colu mn-1\&p_p_col_count=1\&_56_INSTANCE_J6tn_articleId=13867\& 56_INSTANCE_J6tn_groupId=11502\&redirect $=$ http $\% 3 A \% 2 F \% 2 F w$ ww.discoverbiotech.com\%2Findustrial-biotechnology-cntrb\%3Bjsess ionid\%3DEE934F8220E3392CCE2C96581355D320\%3Fp_p_id\%3D 101_INSTANCE_3ZqV\%26p_p_lifecycle\%3D0\%26p_p_state\%3Dn ormal\%26p_p_mode\%3Dview\%26p_p_col_id\%3Dcolumn-1\%26p_p _col_count\%3D1 (Accessed on 16/08/2019)

11. Ammenberg, J.; Anderberg, S.; Lönnqvist, T.; Grönkvist, S.; Sandberg, T. Biogas in the transport sector-actor on the demand side in the Stockholm region. Resour. Conserv. Recycl. 2018, 129, isEP 70-80. is

12. Lyng, K.A.; Stensgård, A.E.; Hanssen, O.J.; Modahl, I.S. Relation between greenhouse gas emissions and stepieconomic profit for different configurations of biogas value chains: A case study on different levels of sector ispintegration. J. Clean. Prod. 2018, 182, 737-745. [CrossRef] istep:

13. Nelabhotla, A.; Dinamarca, C. Bioelectrochemical CO2 Reduction to

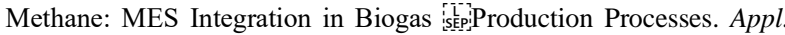
Sci. 2019, 9, 1056. iL

14. Alimahmoodi M and Mulligan CN (2008) Anaerobic bioconversion of carbon dioxide to biogas in an upflow anaerobic sludge blanket reactor. Journal of Air and Waste Management Association 58(1): 95-103.

15. Bewket, W. Biofuel consumption, household level tree planting and its implications for environmental management in the northwestern highlands of Ethiopia. East. Afr. Soc. Sci. Res. Rev. 2005, 21, 19-38

16. Byrns, G., Wheatley, A. And Smedley, V., 2013. Carbon dioxide releases from wastewater treatment: potential use in the UK. Proceedings of the Institute of Civil Engineers - Engineering Sustainability, 166(3), pp.111-121.

\section{AUTHORS PROFILE}

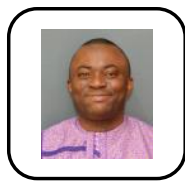

Emetere Moses, is a seasoned researcher with significan awards and experiences. He has over 200 publications in highly rated, peer-reviewed journal.

Adesina Tijesuni is a graduate of Industrial Physics-Elect and IT option. 